Original article

Original articles

https://doi.org/10.17308/kcmf.2021.23/3309

\title{
Synthesis of bismuth ferrite nanopowder doped with erbium ions
}

\author{
E. V. Tomina ${ }^{1,2 \bowtie}$, A. A. Pavlenko ${ }^{2}$, N. A. Kurkin ${ }^{2}$ \\ ${ }^{1}$ Voronezh State University of Forestry and Technologies named after G. F. Morozov, \\ 8 Timiryazeva ul., Voronezh 394087, Russian Federation \\ ${ }^{2}$ Voronezh State University, \\ 1 Universitetskaya pl., Voronezh 394018, Russian Federation
}

\begin{abstract}
The potential for the practical application of bismuth ferrite (BFO) in information storage, microelectronic, and spintronic devices and in medical sensors of various purpose is limited by the presence of a spin cycloid. Its destruction, including destruction due to doping with rare earth elements and the transfer of BFO to a nanoscale state, contributes to the occurrence of ferromagnetism and the manifestation of the magnetoelectric effect. The study was aimed at the synthesis of bismuth ferrite nanopowder doped with erbium ions.

By spray pyrolysis at a temperature of $760{ }^{\circ} \mathrm{C}$, we synthesised BFO samples with a nominal degree of doping with erbium

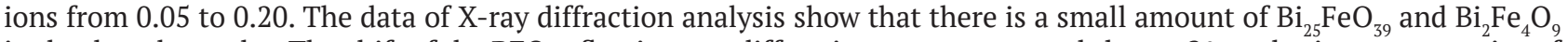
in the doped samples. The shift of the BFO reflections on diffraction patterns towards larger $2 \theta$ angles is representative of the incorporation of erbium ions into the crystal lattice of $\mathrm{BiFeO}_{3}$. The morphological characteristics of the samples were determined using transmission electron microscopy. According to the data of electron probe X-Ray microanalysis, the real composition of the doped $\mathrm{Er}_{\mathrm{x}} \mathrm{Bi}_{1-\mathrm{x}} \mathrm{FeO}_{3}$ samples is very close to the nominal.

The particles of $\mathrm{Er}_{\mathrm{x}} \mathrm{Bi}_{1-\mathrm{x}} \mathrm{FeO}_{3}$ powders synthesised by spray pyrolysis have a nearly spherical shape, the particle-size distribution is in the range of $5-300 \mathrm{~nm}$, the predominant number of particles have a size in the range of 50-200 $\mathrm{nm}$, and the agglomeration is weak. The decrease in the crystal lattice parameters and the unit cell volume of $\mathrm{Er}_{\mathrm{x}} \mathrm{Bi}_{1-\mathrm{x}} \mathrm{FeO}_{3}$ and an increase in the degree of doping with erbium ions confirm the incorporation of $\mathrm{Er}^{3+}$ into the BFO crystal lattice to the bismuth position.
\end{abstract}

Keywords: Nanopowders, Bismuth ferrite, Multiferroics, Doping

Acknowledgements and financial support: the research results were partially obtained using the equipment of Shared Scientific Equipment Centre of Voronezh State University. URL: http://ckp.vsu.ru.

For citation: Tomina E. V., Pavlenko A. A., Kurkin N. A. Synthesis of bismuth ferrite nanopowder doped with erbium ions. Kondensirovannye sredy i mezhfaznye granitsy = Condensed Matter and Interphases. 2021;23(1): 93-100. https://doi. org/10.17308/kcmf.2021.23/3309

Для циитирования: Томина Е. В., Павленко А. А., Куркин Н. А. Синтез нанопорошка феррита висмута, допированного ионами эрбия. Конденсированные среды и межфазные гранищы. 2021;23(1): 93-100. https://doi.org/10.17308/ kcmf.2021.23/3309

Elena V. Tomina, e-mail: tomina-e-v@yandex.ru

(c) Tomina E. V., Pavlenko A. A., Kurkin N. A., 2021 


\section{Introduction}

Among multiferroic materials, bismuth ferrite $\mathrm{BiFeO}_{3}$ is particularly interesting. The symmetry of the BFO crystal allows the presence of the linear magnetoelectric effect and weak ferromagnetism at room temperature [1-5]. However, bismuth ferrite in bulk state is characterised by a spin cycloid in its magnetic structure, with the period of $62 \mathrm{~nm}$. It completely eliminates the weak ferromagnetism of BFO and prevents the appearance of the linear magnetoelectric effect. The inhomogeneity of the magnetoelectric interaction leads to the induction of spatial spin modulation of spontaneous electric polarisation. In the first approximation, the degree of rhombohedral distortion of the cell, the $c / a$ ratio, can be a criterion for the degree of polarisation. To destroy the spin cycloid, it is necessary to decrease the $c / a$ ratio, thereby reducing the degree of polarisation, which results in a change in the spin structure [6-11]. The synthesis of BFO by the solid-phase method is a rather challenging task, since the $\mathrm{Bi}_{2} \mathrm{O}_{3}-\mathrm{Fe}_{2} \mathrm{O}_{3}$ system is characterised by the formation of 3 intermediate phases: $\mathrm{Bi}_{25} \mathrm{FeO}_{39}$, $\mathrm{BiFeO}_{3}$, and $\mathrm{Bi}_{2} \mathrm{Fe}_{4} \mathrm{O}_{9}$; single-phase $\mathrm{BiFeO}_{3}$ exists in a very narrow range of compositions, temperature, and pressure [12-16]. A decrease in the impurity content in $\mathrm{BFO}$ requires long-term heat treatment, which is accompanied by an increase in the particle size of the target product. Unlike the solid-phase method, the synthesis of nanopowders by spray pyrolysis of aerosols has such advantages as sufficiently high productivity, purity of the target product, the ability to control morphology, and low energy consumption. Therefore, the study was aimed at the synthesis of $\mathrm{BiFeO}_{3}$ by spray pyrolysis with different degrees of doping with $\mathrm{Er}^{3+}$ ions.

\section{Experimental}

In this work, crystalline hydrates of $\mathrm{Fe}\left(\mathrm{NO}_{3}\right)_{3} \cdot 9 \mathrm{H}_{2} \mathrm{O}$ (p.a. TU 6-09-02-55396), $\mathrm{Bi}\left(\mathrm{NO}_{3}\right)_{3} \cdot 5 \mathrm{H}_{2} \mathrm{O}$ (p.a. CAS 10035-06-0), $\mathrm{Er}_{2}\left(\mathrm{SeO}_{4}\right)_{3} \cdot 8 \mathrm{H}_{2} \mathrm{O}$ (pur. TU 1083-63), tartaric acid $\mathrm{C}_{4} \mathrm{H}_{6} \mathrm{O}_{6}$ (GOST 5817-77), and nitric acid $\mathrm{HNO}_{3}$ (GOST 4461-77) were used as precursors. The samples were synthesised by the spray pyrolysis method similar to the procedure described in [17]. During the synthesis of erbium-doped bismuth ferrite, the concentration values of bismuth and erbium ions were calculated using the stoichiometric ratio: $\mathrm{Er}^{3+}: \mathrm{Bi}^{3+}: \mathrm{Fe}^{3+}=x:(1-x): 1$, where $x=0.05,0.10,0.15,0.20$ is the nominal doping degree.

In accordance with this ratio, crystalline hydrates of erbium selenate, iron nitrate, and bismuth nitrate were dissolved in nitric acid. Tartaric acid $\mathrm{C}_{4} \mathrm{H}_{6} \mathrm{O}_{6}$, taken at the rate of 3 moles of acid per 2 moles of metal ions, was dissolved in distilled water and added to a solution of metal nitrates. To carry out the synthesis, a laboratory spray pyrolysis unit was assembled (Fig. 1). The prepared solution was placed in a dispersant, where it was transformed into an aerosol with a particle size of 0.8 to $2.0 \mu \mathrm{m}$ and was transferred by an air flow into the reaction chamber of an MTP-2M furnace, the hottest part of which was heated to $760^{\circ} \mathrm{C}$. The temperature was controlled by an OVEN TRM1-Shch1.U.R thermostat with an error of $\pm 1{ }^{\circ} \mathrm{C}$. The flow rate was $9 \mathrm{l} / \mathrm{h}$. Aerosol particles were in the reaction zone for about 0.6 s. Influenced by the high temperature, the aerosol pyrolytically decomposed with the formation of the target product. The particles were collected by passing the gas through a glass of distilled water, then they were filtered off, and dried in air.

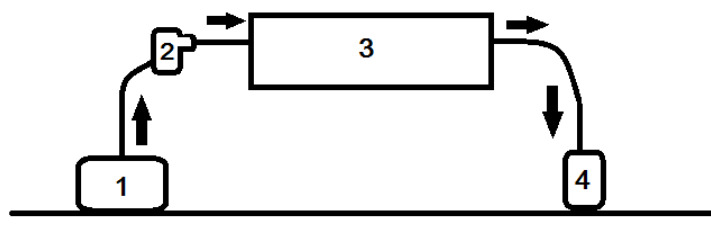

Fig. 1. The layout of the spray pyrolysis unit: 1 - compressor, 2 - dispersant, 3 - MTP-2M furnace, 4 - a glass of distilled water to collect the nanopowder

The phase composition of the synthesised powders $\mathrm{BiFeO}_{3}, \mathrm{BiFeO}_{3}: \mathrm{Er}^{3+}(5 \%)$, and $\mathrm{BiFeO}_{3}: \operatorname{Er}^{3+}(10 \%)$ was determined by X-ray diffraction analysis (XRD), using a RIGAKU SmartLab III X-ray diffractometer with a Co anode $(\lambda=1.79030 \mathrm{~nm})$. The measurement was performed with a step of 0.010 . To study the phase composition of $\mathrm{BiFeO}_{3}: \mathrm{Er}^{3+}(15 \%)$ and $\mathrm{BiFeO}_{3}: \mathrm{Er}^{3+}(20 \%)$ by XRD, we used an Empyrean B.V. X-ray diffractometer with a $\mathrm{Cu}$ anode $(\lambda=1.54060 \mathrm{~nm})$. The scanning was performed within a $2 \theta$ angle range of 10 to $80^{\circ}$ with a step of 0.0200 . The size of the coherent scattering regions (CSR) based on the XRD data of the synthesised bismuth ferrite samples was calculated using the Scherrer formula [18]: 
$D_{h k l}=\frac{k x \lambda}{\beta_{h k l} \times \cos \theta}$,

where: $D_{h k l}$ - average particle size, $\AA$, $k$ - correction factor (for cubic and orthorhombic structure $k=0.9), \lambda-\mathrm{X}$-ray tube wavelength, $\theta-$ the position of the peak maximum, deg., $\beta_{\mathrm{hkl}}$ - intrinsic physical broadening of the diffraction maximum, rad.

The quantitative elemental composition of the synthesised samples was determined by electron probe X-Ray microanalysis (EPXMA, scanning electron microscope JEOL-6510LV with a Bruker energy dispersive microanalysis system).

The size and morphology of BFO powder particles were determined using the results of transmission electron microscopy (TEM, Carl Zeiss Libra-120 transmission electron microscope).

For a semi-quantitative assessment of the content of impurity phases in the synthesised BFO nanopowders, we conducted a semiquantitative analysis of the diffraction patterns by the corundum number method using the formula:

$\omega_{k}=\frac{\frac{I_{k}^{\max }}{R I R_{k}}}{\sum_{i} \frac{I_{i}^{\max }}{R I R_{i}}}$,

where: $\omega_{k}$ - mass fraction of phase $k, I_{k}^{\max }$ - intensity of the largest reflection of phase $k, R I R_{k}-$ corundum number of phase $k, I_{i}^{\max }$ - intensity values of the largest reflections of $i$-phases, $R I R_{i}-$ corundum number of $i$ - phases.

\section{Results and discussion}

The data of X-ray phase analysis (Figs. 2 and 3 ) shows that the synthesised samples are mainly bismuth orthoferrite $\mathrm{BiFeO}_{3}$ (card number 73-0548) [19]. However, there are single reflections of the $\mathrm{Bi}_{25} \mathrm{FeO}_{39}$ and $\mathrm{Bi}_{2} \mathrm{Fe}_{4} \mathrm{O}_{9}$ phases (card numbers 460416, 72-1832). A semi-quantitative assessment of the content of impurity phases in the synthesised samples by the corundum number method demonstrates a tendency for the increase in the amount of $\mathrm{Bi}_{25} \mathrm{FeO}_{39}$ and $\mathrm{Bi}_{2} \mathrm{Fe}_{4} \mathrm{O}_{9}$ with an increase

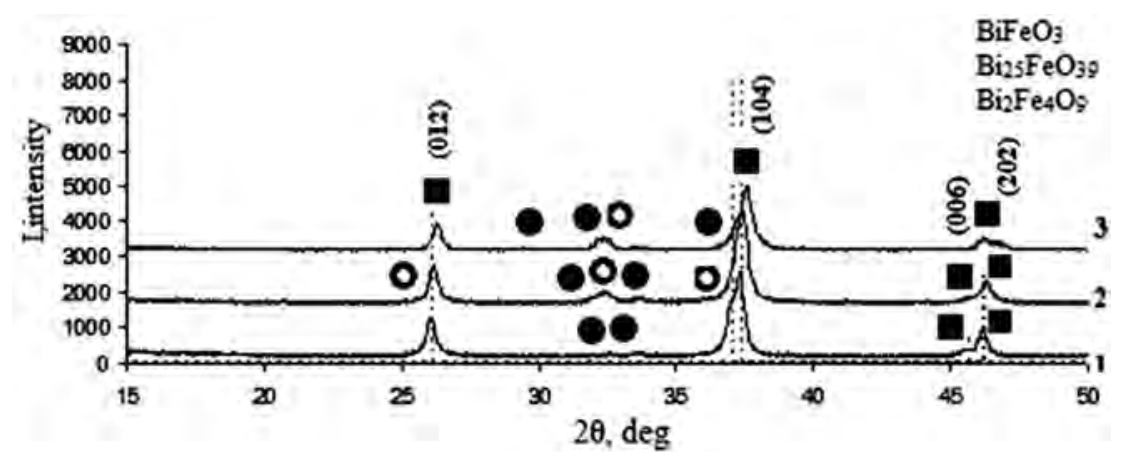

Fig. 2. X-ray diffraction patterns of the samples of $\mathrm{BiFeO}_{3}(1), \mathrm{BiFeO}_{3}: \mathrm{Er}^{3+}(5 \%)$ (2), and $\mathrm{BiFeO}_{3}: \mathrm{Er}^{3+}(10 \%)(3)$. The reflections of the $\mathrm{BiFeO}_{3}$ reference sample are indicated by the dotted line (card number 73-0548)

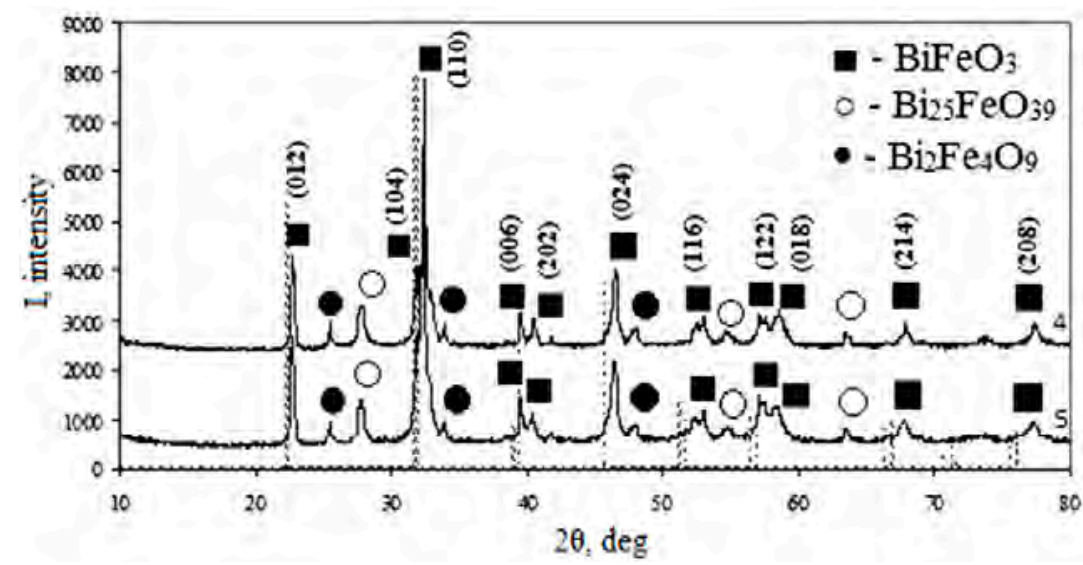

Fig. 3. X-ray diffraction pattern of the $\mathrm{BiFeO}_{3}: \mathrm{Er}^{3+}(15 \%)$ (4) sample and X-ray diffraction pattern of the $\mathrm{BiFeO}_{3}: \mathrm{Er}^{3+}(20 \%)$ (5) sample. The reflections of the $\mathrm{BiFeO}_{3}$ reference sample are indicated by the dotted line (card number 73-0548) 
in the degree of doping of $\mathrm{BFO}$ with $\mathrm{Er}^{3+}$ ions (Table 1 ), which may be associated with an increase in distortions of the crystal lattice of bismuth ferrite.

When the diffraction patterns recorded using the same diffractometer are superposed (Fig. 2 and Fig. 3, respectively), we can see a shift of the reflections of erbium-doped BFO samples toward larger $2 \theta$ angles compared to the undoped $\mathrm{BiFeO}_{3}$ sample. It indicates a distortion of the crystal lattice caused by the incorporation of an ion with a smaller ionic radius to the position of an ion with a larger ionic radius [20]. Since the $\mathrm{Er}^{3+}$ ion radius is $0.089 \mathrm{~nm}$, and the $\mathrm{Bi}^{3+}$ and $\mathrm{Fe}^{3+}$ ion radii are $0.120 \mathrm{~nm}$ and $0.064 \mathrm{~nm}$, respectively [21], it can be assumed that erbium is incorporated into the ferrite lattice to the position of bismuth. This is confirmed by a decrease in the parameters of the crystal lattice and the unit cell volume in relation to an increase in the degree of doping of bismuth ferrite with erbium ions (Table 2).
The energy dispersive spectra of the synthesised $\mathrm{Er}_{x} \mathrm{Bi}_{1-x} \mathrm{FeO}_{3}$ samples record not only the signals of $\mathrm{Bi}, \mathrm{Fe}$, and $\mathrm{O}$, but also Er (Fig. 4), which also confirms that erbium ions incorporate into the BFO lattice. With an increase in the degree of doping of bismuth ferrite, the intensity of erbium signals in the synthesised samples expectedly increases. Nevertheless, the real composition of the synthesised samples of $\mathrm{BiFeO}_{3}: \mathrm{Er}^{3+}(5 \%)$, $\mathrm{BiFeO}_{3}: \mathrm{Er}^{3+}(10 \%)$, and $\mathrm{BiFeO}_{3}: \mathrm{Er}^{3+}(15 \%)$ is slightly different from the nominal (Table 3), which is explained by the presence of a certain amount of $\mathrm{Bi}_{25} \mathrm{FeO}_{39}$ and $\mathrm{Bi}_{2} \mathrm{Fe}_{4} \mathrm{O}_{9}$ impurity phases in doped BFO nanopowders.

The size assessment CSR based on the XRF data is provided in Table 4 . The average CSR of $\mathrm{Er}_{x} \mathrm{Bi}_{1-x} \mathrm{FeO}_{3}$ sample particles is within the range of 19 to $27 \mathrm{~nm}$, it slightly raises with an increase in the nominal degree of BFO doping with $\mathrm{Er}^{3+}$ ions from 0.05 to 0.20 .

Table 1. The composition of the synthesised samples, calculated by the method of corundum numbers

\begin{tabular}{c|c|c|c|c|c}
\hline \multirow{2}{*}{ Phase, wt.\% } & \multicolumn{5}{|c}{ Samples } \\
\cline { 2 - 6 } & $\mathrm{BiFeO}_{3}$ & $\begin{array}{c}\mathrm{BiFeO}_{3}: \mathrm{Er}^{3+} \\
(5 \%)\end{array}$ & $\begin{array}{c}\mathrm{BiFeO}_{3}: \mathrm{Er}^{3+} \\
(10 \%)\end{array}$ & $\begin{array}{c}\mathrm{BiFeO}_{3}: \mathrm{Er}^{3+} \\
(15 \%)\end{array}$ & $\begin{array}{c}\mathrm{BiFeO}_{3}: \mathrm{Er}^{3+} \\
(20 \%)\end{array}$ \\
\hline $\mathrm{BiFeO}_{3}$ & $95.7 \%$ & $84.3 \%$ & $72.6 \%$ & $75.4 \%$ & $72.1 \%$ \\
\hline $\mathrm{Bi}_{25} \mathrm{FeO}_{39}$ & $0.0 \%$ & $12.0 \%$ & $19.1 \%$ & $15.7 \%$ & $16.4 \%$ \\
\hline $\mathrm{Bi}_{2} \mathrm{Fe}_{4} \mathrm{O}_{9}$ & $4.3 \%$ & $3.7 \%$ & $8.3 \%$ & $8.9 \%$ & $11.5 \%$ \\
\hline
\end{tabular}

Table 2 The lattice parameters and unit cell volume of $\mathrm{BiFeO}_{3}$ samples: $\mathrm{BiFeO}_{3}: \mathrm{Er}^{3+}(5 \%), \mathrm{BiFeO}_{3}: \mathrm{Er}^{3+}$ $(10 \%), \mathrm{BiFeO}_{3}: \mathrm{Er}^{3+}(15 \%)$, and $\mathrm{BiFeO}_{3}: \mathrm{Er}^{3+}(20 \%)$, synthesised by spray pyrolysis (calculated for hexagonal packing)

\begin{tabular}{c|c|c|c|c|c|c}
\hline $\begin{array}{c}\text { Lattice } \\
\text { parameters }\end{array}$ & $\begin{array}{c}\text { Reference sample, } \mathrm{BiFeO}_{3} \\
\text { Card 73-0548 }\end{array}$ & $\mathrm{BiFeO}_{3}$ & $\begin{array}{c}\mathrm{BiFeO}_{3}: \mathrm{Er}^{3+} \\
(5 \%)\end{array}$ & $\begin{array}{c}\mathrm{BiFeO}_{3}: \mathrm{Er}^{3+} \\
(10 \%)\end{array}$ & $\begin{array}{c}\mathrm{BiFeO}_{3}: \mathrm{Er}^{3+} \\
(15 \%)\end{array}$ & $\begin{array}{c}\mathrm{BiFeO}_{3}: \mathrm{Er}^{3+} \\
(20 \%)\end{array}$ \\
\hline$a, \AA$ & 5.58 & 5.58 & 5.56 & 5.55 & 5.46 & 5.44 \\
\hline $\mathrm{c}, \AA$ & 13.90 & 13.85 & 13.82 & 13.71 & 13.67 & 13.66 \\
\hline$V, \AA^{3}$ & 374.81 & 373.41 & 370.68 & 369.09 & 352.71 & 350.75 \\
\hline
\end{tabular}

Table 3. Results of the electron probe X-Ray microanalysis for the samples of $\mathrm{BiFeO}_{3}: \mathrm{Er}^{3+}(5 \%)$, $\mathrm{BiFeO}_{3}: \operatorname{Er}^{3+}(10 \%)$, and $\mathrm{BiFeO}_{3}: \operatorname{Er}^{3+}(15 \%)$

\begin{tabular}{|c|c|c|c|c|c|}
\hline \multicolumn{3}{|c|}{ Nominal composition of samples $(\mathrm{N})$} & $\mathrm{Er}_{0.05} \mathrm{Bi}_{0.95} \mathrm{FeO}_{3}$ & $\mathrm{Er}_{0.10} \mathrm{Bi}_{0.90} \mathrm{FeO}_{3}$ & $\mathrm{Er}_{0.15} \mathrm{Bi}_{0.85} \mathrm{FeO}_{3}$ \\
\hline \multirow{8}{*}{$\begin{array}{l}\text { Elemental } \\
\text { composition, } \\
\text { at. \% }\end{array}$} & \multirow{2}{*}{ Er } & $\mathrm{H}$ & 1.00 & 2.00 & 3.00 \\
\hline & & $P$ & 1.17 & 2.24 & 3.32 \\
\hline & \multirow{2}{*}{$\mathrm{Bi}$} & $\mathrm{H}$ & 19.00 & 18.00 & 17.00 \\
\hline & & $\mathrm{P}$ & 18.07 & 18.00 & 15.72 \\
\hline & \multirow{2}{*}{$\mathrm{Fe}$} & $\mathrm{H}$ & 20.00 & 20.00 & 20.00 \\
\hline & & $\mathrm{P}$ & 20.09 & 19.76 & 20.96 \\
\hline & \multirow{2}{*}{$\mathrm{O}$} & $\mathrm{H}$ & 60.00 & 60.00 & 60.00 \\
\hline & & $\mathrm{P}$ & 59.83 & 60.00 & 60.00 \\
\hline \multicolumn{3}{|c|}{ Real composition of samples (R) } & $\mathrm{Er}_{0.05} \mathrm{Bi}_{0.90} \mathrm{FeO}_{2.98}$ & $\mathrm{Er}_{0.11} \mathrm{Bi}_{0.91} \mathrm{FeO}_{3}$ & $\mathrm{Er}_{0.16} \mathrm{Bi}_{0.75} \mathrm{FeO}_{2.86}$ \\
\hline
\end{tabular}



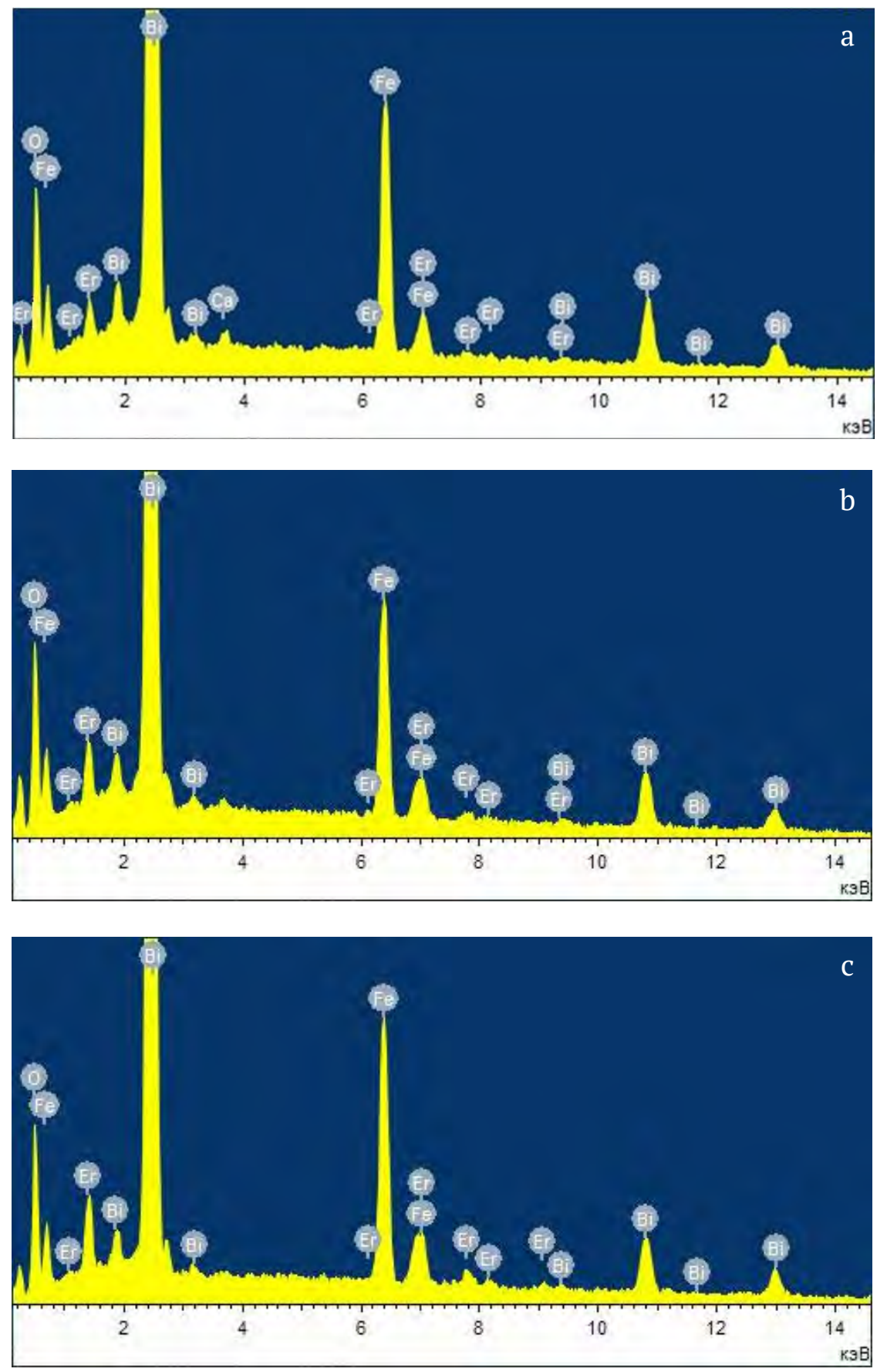

Fig. 4. The energy dispersive spectra of the samples: a) $\mathrm{BiFeO}_{3}: \mathrm{Er}^{3+}(5 \%)$; b) $\mathrm{BiFeO}_{3}: \mathrm{Er}^{3+}$ (10 \%), c) $\mathrm{BiFeO}_{3}: \mathrm{Er}^{3+}$ (15\%), synthesised by spray pyrolysis

Table 4. CSR values of particles of the $\mathrm{Er}_{x} \mathrm{Bi}_{1-\mathrm{x}} \mathrm{FeO}_{3}$ samples synthesised by spray pyrolysis

\begin{tabular}{c|c|c|c|c|c}
\hline $\begin{array}{c}\text { CSR diameter } \\
\text { of particles, } \mathrm{nm}\end{array}$ & $\mathrm{BiFeO}_{3}$ & $\mathrm{Er}_{0.05} \mathrm{Bi}_{0.95} \mathrm{FeO}_{3}$ & $\mathrm{Er}_{0.10} \mathrm{Bi}_{0.90} \mathrm{FeO}_{3}$ & $\mathrm{Er}_{0.15} \mathrm{Bi}_{0.85} \mathrm{FeO}_{3}$ & $\mathrm{Er}_{0.20} \mathrm{Bi}_{0.80} \mathrm{FeO}_{3}$ \\
\hline$D_{1}$ & $22 \pm 2$ & $22 \pm 2$ & $22 \pm 2$ & $26 \pm 3$ & $30 \pm 3$ \\
\hline $\mathrm{D}_{2}$ & $14 \pm 1$ & $16 \pm 2$ & $16 \pm 2$ & $21 \pm 2$ & $26 \pm 3$ \\
\hline$D_{3}$ & $18 \pm 2$ & $18 \pm 2$ & $23 \pm 2$ & $23 \pm 2$ & $26 \pm 3$ \\
\hline$D_{\text {cp }}$ & $18 \pm 2$ & $19 \pm 2$ & $20 \pm 2$ & $23 \pm 2$ & $27 \pm 3$ \\
\hline
\end{tabular}


According to the TEM data (Fig. 5), the $\mathrm{Er}_{0.05} \mathrm{Bi}_{0.95} \mathrm{FeO}_{3}$ particles have a nearly spherical shape, the particle size does not exceed $300 \mathrm{~nm}$, and the predominant fraction of the particles is in the range of 51-100 nm. For a sample with a higher degree of doping with $\mathrm{Er}_{0.15} \mathrm{Bi}_{0.85} \mathrm{FeO}_{3}$, a weakly pronounced agglomeration is observed (Fig. 6). Although the particle size still does not exceed $300 \mathrm{~nm}$, most of the particles have a size in the range of 101-200 nm.

\section{Conclusions}

We determined that spray pyrolysis makes it possible to synthesise bismuth ferrite nanopowders with various degrees of doping with erbium, which are characterised by
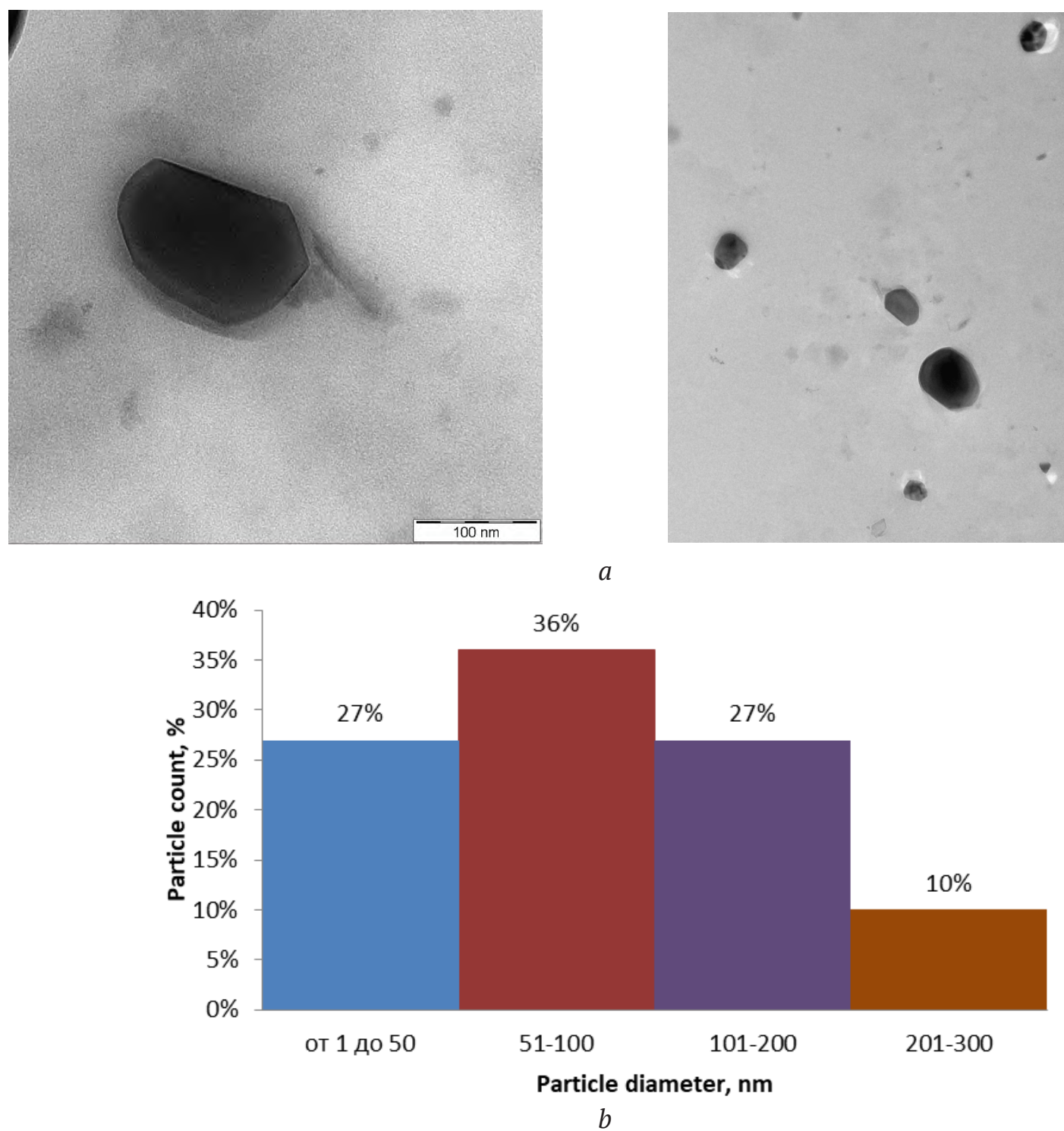

Fig. 5. TEM images (a) of the $\mathrm{Er}_{0.05} \mathrm{Bi}_{0.95} \mathrm{FeO}_{3}$ sample synthesised by spray pyrolysis, in the gelatinous layer, and the histogram of its particle-size distribution (b)

pronounced crystallinity, a low degree of agglomeration, a nearly spherical shape, and a predominant particle size within the range of $50-200 \mathrm{~nm}$. The shift of the reflections of bismuth ferrite towards larger values of $2 \theta$ angles, observed in the diffraction patterns, a decrease in the lattice parameters and the unit cell volume of $\mathrm{Er}_{x} \mathrm{Bi}_{1-x} \mathrm{FeO}_{3}$ samples, as well as an increase in the degree of doping with erbium ions indicate the incorporation of erbium ions into the crystal lattice of ferrite at the bismuth position.

\section{Conflict of interests}

The authors declare that they have no known competing financial interests or personal

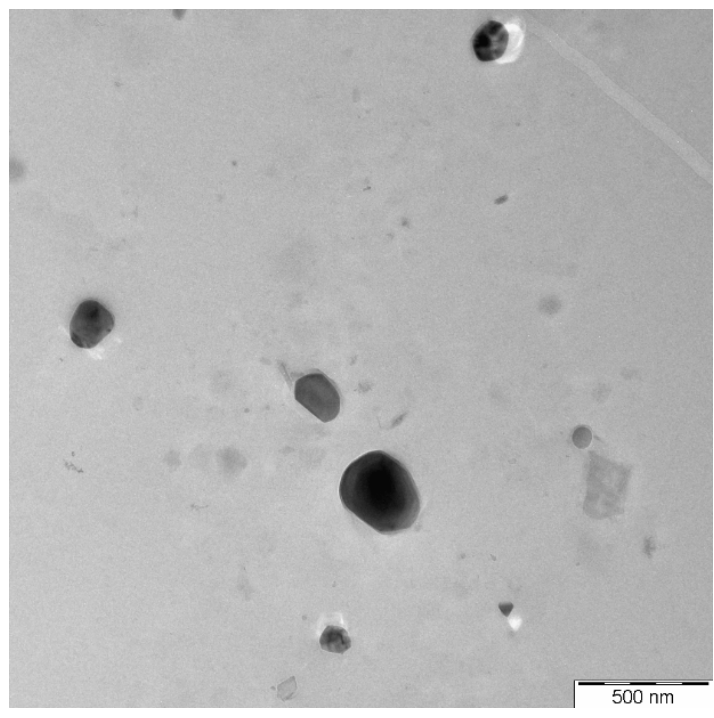

$a$ 

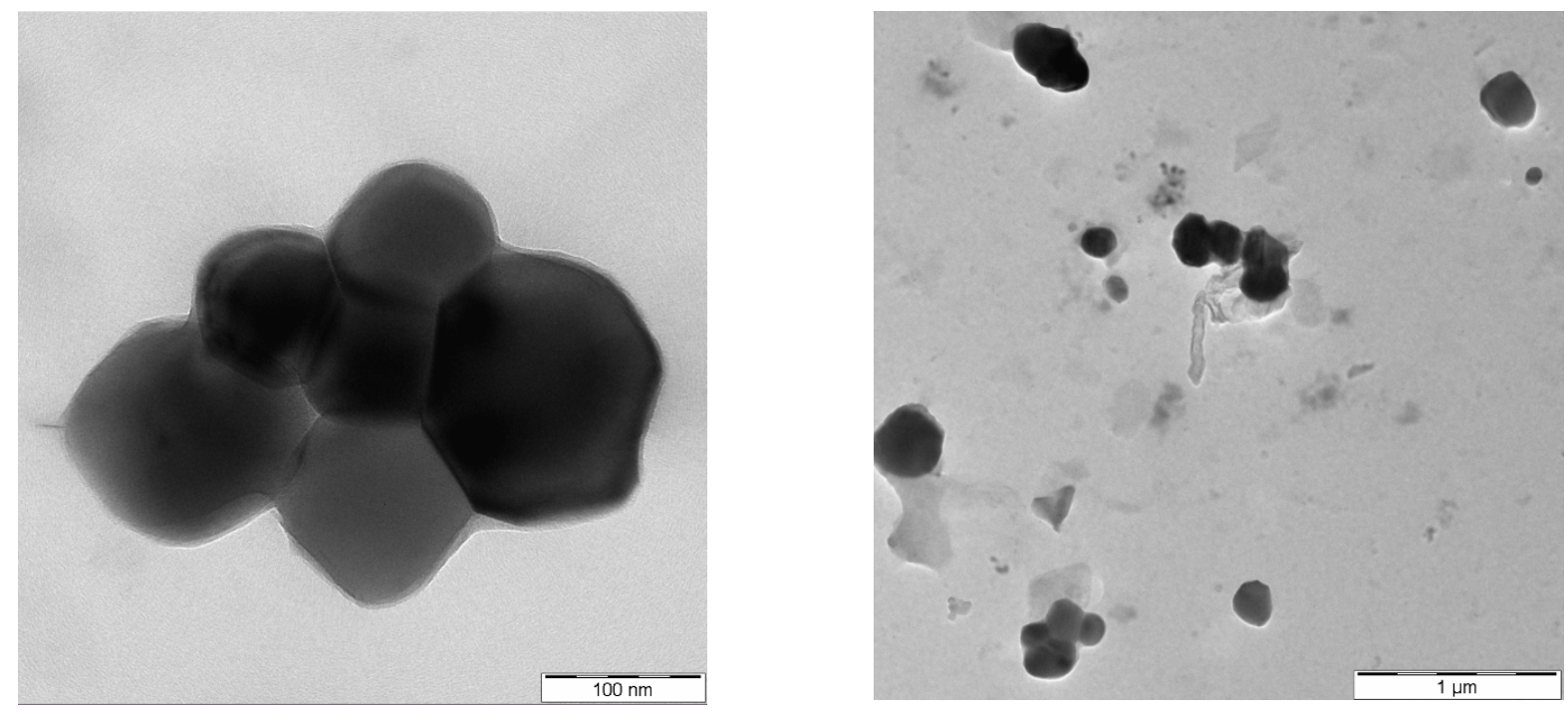

$a$

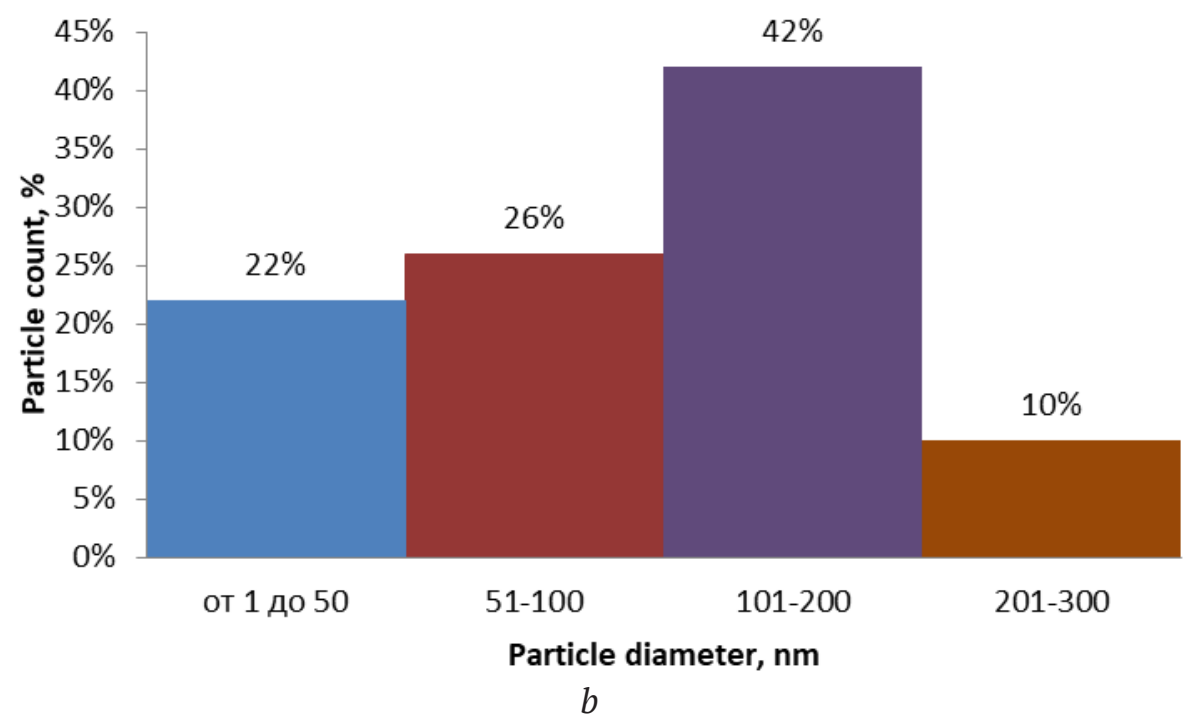

Fig. 6. TEM images (a) of the $\mathrm{Er}_{0.15} \mathrm{Bi}_{0.85} \mathrm{FeO}_{3}$ sample synthesised by spray pyrolysis, in the gelatinous layer, and the histogram of its particle-size distribution (b)

relationships that could have influenced the work reported in this paper.

\section{References}

1. Dai Z. Fujita Y., Akishige Y. Dielectric properties and heating effect of multiferroic $\mathrm{BiFeO}_{3}$ suspension. Materials Letters. 2011;63(13): 2036-2039. https://doi. org/10.1016/j.matlet.2011.04.029

2. Lin Z., Cai W., Jiang W., Fu Ch., Li Ch., Song Y. Ceramics International. 2013;39(8): 8729-8736. https:// doi.org/10.1016/j.ceramint.2013.04.058

3. Selbach S. M., Tybell T., Einarsrud M. Chemistry of materials. 2007;19(26): 6478-6484. https://doi. org/10.1021/cm071827w

4. Shirokov V. B., Golovko Yu. I., Mukhortov V. M. Technical physics. 2014;59(1): 102-106. https://doi. org/10.1134/s1063784214010174
5. Karthikeyan K., Thirumoorthi A. Nanosystems: Physics, Chemistry, Mathematics. 2018;9: 631-640. https://doi.org/10.17586/2220-8054-2018-9-5-631640

6. Fiebig M. Revival of the magnetoelectric effect. Journal of Physics D: Applied Physics. 2005;38(8): R123R152. https://doi.org/10.1088/0022-3727/38/8/r01

7. Eerenstein W., Mathur N. D., Scott J. F. Multiferroic and magnetoelectric materials. Nature. 2006;442(7104): 759-765. https://doi.org/10.1038/ nature 05023

8. Cheong S.-W., Mostvoy M. Multiferroics: a magnetic twist for ferroelectricity. Nature Materials. 2007;6(1): 13-20. https://doi.org/10.1038/nmat1804

9. Ramesh R., Spaldin N.A. Multiferroics: progress and prospects in thin films. Nature Materials. 2007;6(1): 21-29. https://doi.org/10.1038/nmat1805 
10. Tokura Y. Multiferroics-toward strong coupling between magnetization and polarization in a solid. Journal of Magnetism and Magnetic Materials... 2007;310(2): 1145-1150. https://doi.org/10.1016/j. jmmm.2006.11.198

11. Catalan G., Scott J. F. Physics and applications of bismuth ferrite. Advanced Materials. 2009;21(24): 2463-2485. https://doi.org/10.1002/adma.200802849

12. Morozov M. I., Lomanova N. A., Gusarov V. V. Specific features of $\mathrm{BiFeO}_{3}$ formation in a mixture of bismuth(III) and iron(III) oxides. Russian Journal of General Chemistry. 2003;73(11): 1676-1680. https:// doi.org/10.1023/b:rugc.0000018640.30953.70

13. Liu T., Xu Y., Zhao J. Low-temperature synthesis of $\mathrm{BiFeO}_{3}$ via PVA sol-gel route. Journal of the American Ceramic Society. 2010;93(11): 3637-3641. https://doi.org/10.1111/j.1551-2916.2010.03945.X

14. Feroze A., Idrees M., Kim D. K., Nadeem M., Siddiqi S. A., Shaukat S. F., Atif M., Siddique M. Low temperature synthesis and properties of $\mathrm{BiFeO}_{3}$. Journal of Electronic Materials. 2017;46(7): 4582-4589. https://doi.org/10.1007/s11664-017-5463-3

15. Egorysheva A. V., Kuvshinova T. B., Volodin V. D., Ellert O. G., Efimov N. N., Skorikov V. M., Baranchikov A. E., Novotortsev V. M. Synthesis of highpurity nanocrystalline $\mathrm{BiFeO}_{3}$. Inorganic materials. 2013;49(3): 310-314. https://doi.org/10.1134/ s0020168513030035

16. Selbach S. M., Tybell T., Einarsrud M. A., Grande T. Phase transitions, electrical conductivity and chemical stability of $\mathrm{BiFeO}_{3}$ at high temperatures. Journal of Solid State Chemistry. 2010;183(5): 12051208. https://doi.org/10.1016/j.jssc.2010.03.014

17. Tomina E. V., Lastochkin D. A., Maltsev S. A. The synthesis of nanophosphors $\mathrm{YP}_{x} \mathrm{~V}_{1-x} \mathrm{O}_{4}$ by spray pyrolysis and microwave methods. Kondensirovannye sredy $i$ mezhfaznye granitsy = Condensed Matter and Interphases. 2020;22(4): 496-503. https://doi. org/10.17308/kcmf.2020.22/3120
18. Brandon D., Kaplan U. Microstructure of materials. Research and control methods. John Wiley \& Sons Ltd; 1999.

19. JCPDS PCPDFWIN: A Windows Retrieval / Display program for Accessing the ICDD PDF-2 Data base, International Centre for Diffraction Data, 1997.

20. Bhat I., Husain S., Khan W., Patil S. I. Effect of Zn doping on structural, magnetic and dielectric properties of $\mathrm{LaFeO}_{3}$ synthesized through sol-gel auto-combustion process. Materials Research Bulletin. 2013;48(11): 4506-4512. https://doi.org/10.1016/j. materresbull.2013.07.028

21. Tret'yakov Yu. D. [et al.]. Neorganicheskaya khimiya. Khimiya elementov: uchebnik dlya stud. vuzov, obuch. po napravleniyu 510500 "Khimiya" $i$ spetsial'nosti 011000 "Khimiya”: $v 2$ t. [Inorganic chemistry. Chemistry of elements: a textbook for students. universities, studying under programme 510500 "Chemistry" and for speciality 011000 "Chemistry": in 2 vol.] Moscow: Akademkniga Publ.; 2007. V. 1. 538 p.; V. 2. 670 p. (In Russ.)

\section{Information about the authors}

Elena $V$. Tomina, DSc in Chemistry, Head of the Department of Chemistry, Voronezh State University of Forestry and Technologies, Voronezh, Russian Federation; e-mail: tomina-e-v@yandex.ru. ORCID iD: https://orcid.org/0000-0002-5222-0756.

Anna A. Pavlenko, a 1st year master's student, Voronezh State University, Voronezh, Russian Federation; e-mail: anna.pavlienko.1999@mail.ru ORCID iD: https://orcid.org/0000-0003-4899-609X

Nikolay A. Kurkin, a 2nd year master's student, Voronezh State University, Voronezh, Russian Federation; e-mail:kurkin.nik@yandex.ru.ORCID iD: https://orcid.org/0000-0002-0468-8207

All authors read and approved the final manuscript.

Received 17 January 2021; Approved after reviewing 15 February 2021; Accepted 15 March 2021; Published online 25 March 2021.

Translated by Anastasiia Ananeva

Edited and proofread by Simon Cox 